\title{
Length-Weight, Length-Length Relationships and Condition Factor of Chondrostoma regium (Heckel, 1843) and Barbus lacerta, Heckel, 1843 From Karasu River (East Anatolia, Turkey)
}

\author{
Osman Serdar, Ebru İfakat Özcan* \\ Faculty of Fisheries, Munzur University, 62000 Tunceli, Turkey \\ A R T I C LE I N F O \\ A B S T R A C T

\section{Research Article} \\ Received 05 January 2018 \\ Accepted 30 March 2018 \\ Keywords: \\ Freshwater fishes \\ LWR \\ LLR \\ Condition factor \\ Karasu River

\begin{abstract}
Length-weight, length-length relationships and condition factors were estimated for two fish species (Chondrostoma regium, Barbus lacerta) caught between October 2014 and September 2015 in the 14 distinct locations of Karasu River, East Anatolia, Turkey. Minimum and maximum total length and weight were observed at 7.5 to $31.0 \mathrm{~cm}$ and from 5.7 to $280 \mathrm{~g}$ for C. regium, 7.0 to $24.0 \mathrm{~cm}$ and from $4.0-211 \mathrm{~g}$ for B. lacerta. The $b$ values determined as 2.77 for Chondrostoma regium; 3.10 for Barbus lacerta. The types of growth were found negative allometric for $C$. regium and isometric growth for $B$. lacerta. The length-length relations between total, fork, and standard lengths for the two fish species were highly significant. The relative condition factor values were found to $1.102 \pm 0.013$ for $C$. regium; $1.176 \pm 0.019$ for $B$. lacerta. This study submits for the first time LWR, LLR and condition factor of two species in the Karasu River.
\end{abstract}

\author{
"Corresponding Author: \\ E-mail: ebruozer@munzur.edu.tr
}

\section{Introduction}

Length-weight relationships (LWRs) and lengthlength relationships (LLRs) are important tools in fishery research, management and assessment (Ak et al., 2009). Estimating length-weight relationship (LWR) is considered to be a regular research work of fisheries scientists (Froese, 2006) and has a wide range of application in the field of fish population dynamics. It helps to describe some of the basic biological characteristics and provide information on growth status of fishes (Tesch, 1971). Length-length $(L-L)$ relations are used for conversion between lengths (Basusta et al., 2013). In addition, LWRs and LLRs of fishes are used to estimate the condition of fish (weight and biomass) when only length measurements are available and are helpful about compare of life of species between habitats (Binohlan and Pauly, 1998). The value of condition factor is used to measure the condition or health of a species and permits the understanding of general condition, growth and reproduction of fish (Pauly, 1993). The purpose of this study is to state the length-weight, length-length relationships and condition factor of Chondrostoma regium and Barbus lacerta from Karasu River.

\section{Materials and Methods}

The study is carried out in 14 different stations of the Karasu River. Coordinates of the sampling stations are given in Table 1. Fish samples (232 C. regium and 162 B. lacerta) were caught between October 2014 and September 2015 by electroshocker, gill nets, trammel nets from Karasu River (Figure 1). Fish samples were transported to the laboratory and fixed with 5\% formaldehid. Two fish samples were measured for total, fork and standard length (TL, FL, SL, in $\mathrm{cm}$ ) and total weight $(\mathrm{W}$, in $\mathrm{g})$.

The length-weight relationships were calculated using the equation: $W=a \times L^{b}$, (W= total weight, $L=$ total length, $a=$ intercept of the regression and $b=$ slope or regression coefficient); (King, 1995). The $b$ value for these two species were examined by a $t$-test at the 0.05 importance level to confirm if it was considerably different from 3. Values of the exponent $b$ provide information on fish growth. When $b=3$, increase in weight is isometric. When the value of $b$ is other than 3 , weight increase is allometric (positive allometric if $b>3$, negative allometric if $b<3$ ) (Sangün et al., 2007). In the length weight equation $a$ and $b$ are intercept and the slope of the length weight skew, respectively (Turker-Cakır et al., 2008). Confidence 
intervals of the parameter $b$ were computed by the determination coefficient, $R^{2}$. All statistical analyses were formed with $95 \%$ confidence limits using Excel 2013 and SPSS package version 24. Length-length relationships were estimated as $F L=a+b S L, \quad S L=a+b T L$ and
$T L=a+b F L$ using linear regression analysis. Relative condition factor of examined fish species were estimated by the equation Condition factor $(C F)=\left(W / T L^{3}\right) \times 100$ by using total weight $(\mathrm{g})$ and total length $(\mathrm{cm})$ (Le Cren (1951)).

Table 1. Geographic locations of the Karasu River during the study area

\begin{tabular}{|c|c|c|c|}
\hline Station & Date & Location & Coordinate \\
\hline 1 & 22.05 .2015 & Yeşildağ Stream & $40^{\circ} 08^{\prime} 13^{\prime \prime} \mathrm{N} 41^{\circ} 25^{\prime} 49^{\prime \prime} \mathrm{E}$ \\
\hline 2 & 22.05 .2015 & Yeșildere Stream & $40^{\circ} 08^{\prime} 21^{\prime \prime} \mathrm{N} 41^{\circ} 24^{\prime} 25^{\prime \prime} \mathrm{E}$ \\
\hline 3 & 22.05 .2015 & Köşk Stream & $40^{\circ} 05^{\prime} 45^{\prime \prime} \mathrm{N} 41^{\circ} 24^{\prime} 48^{\prime \prime} \mathrm{E}$ \\
\hline 4 & 22.05 .2015 & Ağasuyu Stream & $39^{\circ} 59^{\prime} 35^{\prime} \mathrm{N} 41^{\circ} 08^{\prime} 56^{\prime \prime} \mathrm{E}$ \\
\hline 5 & 23.05 .2015 & Sincan Stream & $39^{\circ} 59^{\prime} 40^{\prime \prime} \mathrm{N} 41^{\circ} 071^{\prime} 21^{\prime \prime} \mathrm{E}$ \\
\hline 6 & 23.05 .2015 & Çiğdemli Stream & 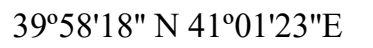 \\
\hline 7 & 23.05 .2015 & Han Stream & $39^{\circ} 56^{\prime} 53^{\prime \prime} \mathrm{N} 40^{\circ} 46^{\prime} 08^{\prime \prime} \mathrm{E}$ \\
\hline 8 & 23.05 .2015 & Taşağıl Stream & $39^{\circ} 57^{\prime} 44^{\prime \prime} \mathrm{N} 40^{\circ} 34^{\prime} 40^{\prime \prime} \mathrm{E}$ \\
\hline 9 & 24.05 .2015 & Karataş Stream & $39^{\circ} 56^{\prime} 13^{\prime \prime} \mathrm{N} 40^{\circ} 07^{\prime} 51^{\prime \prime} \mathrm{E}$ \\
\hline 10 & 24.05 .2015 & Büyükgözenin Stream & $39^{\circ} 56^{\prime} 39^{\prime \prime} \mathrm{N} 40^{\circ} 15^{\prime} 03^{\prime \prime} \mathrm{E}$ \\
\hline 11 & 24.05 .2015 & Deliçay Stream & $39^{\circ} 38^{\prime} 08^{\prime \prime} \mathrm{N} 39^{\circ} 20^{\prime} 18^{\prime \prime} \mathrm{E}$ \\
\hline 12 & 24.05 .2015 & Karn1 Stream & $39^{\circ} 40^{\prime} 24^{\prime \prime} \mathrm{N} 39^{\circ} 13^{\prime} 34^{\prime \prime} \mathrm{E}$ \\
\hline 13 & 24.05 .2015 & Eriç Stream & $39^{\circ} 30^{\prime} 36^{\prime \prime} \mathrm{N} 38^{\circ} 53^{\prime} 14^{\prime \prime} \mathrm{E}$ \\
\hline 14 & 24.05 .2015 & Kırık Stream & $39^{\circ} 29^{\prime} 23^{\prime \prime} \mathrm{N} 38^{\circ} 44^{\prime} 37^{\prime \prime E}$ \\
\hline
\end{tabular}



Figure 1 Sampling sites on the Karasu River

\section{Results and Discussion}

Length-weight, length-length relationships and condition factor were determined 232 C. regium and 162 B. lacerta from Karasu River. The number of samples, TL (minimum-maximum), weight (minimum-maximum), length-weight relationship parameters $(a, b, 95 \%$ CI- $b)$ and coefficient of determination $\left(R^{2}\right)$ are presented in Table 2. Minimum and maximum total length and weight were observed at 7.5 to $33.0 \mathrm{~cm}$ and from 5.7 to $280 \mathrm{~g}$ for C. regium, 7.0 to $24.0 \mathrm{~cm}$ and from $4.0-211 \mathrm{~g}$ for $B$. lacerta.
In the present study, LWRs were highly significant; all specimen were determined between length and weight highly positive relations and the determination coefficient $\left(R^{2}\right)$ values were greater than $96 \%$ in all specimen. These high values of $R^{2}$ show that the length relationships are linear observed range of values. Regression analyses are shown that fish length have high significant correlation with weight $(\mathrm{P}<0.001)$ for two species. Furthermore, when the t-test results were analyzed for the significance of regression coefficients $(\mathrm{P}<0.01)$, it was found that fish- 
length data could be used in high accuracy to predict fish weight (Basusta et al., 2017; Ozcan and Serdar, 2018).

The length-weight relationships of $C$. regium were found as $\mathrm{W}=0.0191 \mathrm{~L}^{2.79}$ in females, $\mathrm{W}=0.0219 \mathrm{~L}^{2.74}$ in males and $\mathrm{W}=0.0202 \mathrm{~L}^{2.77}$ in all individuals (Figure 2). The length-weight relationships of B. lacerta were found as $\mathrm{W}=0.00901 \mathrm{~L}^{3.11}$ in females, $\mathrm{W}=0.0091 \mathrm{~L}^{3.08}$ in males and $\mathrm{W}=0.0090 \mathrm{~L}^{3.10}$ in all individuals (Figure 3 ). Froese (2006) expressed that the parameter $b$ should normally range between 2.5 to 3.5 and Tesch (1971) reported values of $b$ parameter varies usually between 2 and 4 . In this study, $b$ values were determined as 2.77 for $C$. regium (Figure 2), 3.10 for B. lacerta (Figure 3) in Karasu River. The student's t-test showed that the $b$ value of $C$. regium



Figure 2 Length-weight relationship all individuals of Chondrostoma regium from Karasu River was importantly lower than the theoretical value of 3 $(\mathrm{P}<0.05)$ demonstrating negative allometric growth, whereas the student t-test for B. lacerta was demonstrated isometric growth pattern, with no significant difference from the theoretical " $b$ " value of 3 ( $\mathrm{P}<0.05)$; (Table 2).

The parameters of length-weight relationship and minmax total length values of two species reported from different studies are presented in Table 3.

Length-length relationship parameters ( $\alpha$ and $b$ ) and $R^{2}$ are showed in Table 4. Length-length relationships were important $(\mathrm{P}<0.001)$ for two species and $R^{2}$ values bigger than 0.98 .



Figure 3 Length-weight relationship all individuals of Barbus lacerta from Karasu River

Table 2 Length-weight relationship parameters for two species captured between October 2014 and September 2015 , Karasu River

\begin{tabular}{|c|c|c|c|c|c|c|c|c|c|}
\hline \multirow{2}{*}{ Species } & \multirow{2}{*}{ Sex } & \multirow{2}{*}{$\mathrm{n}$} & \multirow{2}{*}{$\mathrm{L}_{\min }{ }^{-\max }$} & \multirow{2}{*}{$\mathrm{W}_{\min }{ }^{-\max }$} & \multicolumn{4}{|c|}{ Regression parameters $\left(\mathrm{W}=\mathrm{aL}^{\mathrm{b}}\right)$} & \multirow{2}{*}{ GT } \\
\hline & & & & & $a$ & $b$ & $95 \% \mathrm{CI}$ of $\mathrm{b}$ & $R^{2}$ & \\
\hline \multirow{3}{*}{ C. regium } & q & 126 & $7.5-31.0$ & $5.7-280$ & 0.0191 & 2.79 & $2.43-2.97$ & 0.98 & \multirow{3}{*}{ A - } \\
\hline & $\hat{o}$ & 106 & $8.0-30.8$ & $7.3-274$ & 0.0219 & 2.74 & $2.67-2.94$ & 0.96 & \\
\hline & $q+0$ & 232 & $7.5-31.0$ & $5.7-280$ & 0.0202 & 2.77 & $2.43-2.97$ & 0.98 & \\
\hline \multirow{3}{*}{ B. lacerta } & q & 97 & $6.9-22.6$ & $3.5-174$ & 0.0090 & 3.11 & $2.99-3.42$ & 0.98 & \multirow{3}{*}{ I } \\
\hline & $\hat{0}$ & 65 & $7.0-24.0$ & $4.0-211$ & 0.0091 & 3.08 & $2.97-3.22$ & 0.98 & \\
\hline & $++\hat{0}$ & 162 & $7.0-24.0$ & $4.0-211$ & 0.0090 & 3.10 & $2.85-3.31$ & 0.99 & \\
\hline
\end{tabular}

$\mathrm{n}$, number of individuals; $\mathrm{L}_{\min ^{-} \max }$ : Total Length, $\mathrm{W}_{\min { }^{-m a x}}$ : Total body weight, a, intercept; $\mathrm{b}$, slope; $\mathrm{R}^{2}$, coefficient of determination; CI, confidence intervals; GT:Type of growth, A+ : positive allometric; A-: negative allometric; I: isometric;

Table 3 The parameters of length-weight relationship and $\mathrm{L}_{\min }-\mathrm{L}_{\max }$ of two species reported from different studies

\begin{tabular}{c|lccccc}
\hline Species & \multicolumn{1}{c}{ Locality } & $\mathrm{n}$ & $\mathrm{L}_{\min }{ }^{-\max }$ & $a$ & $b$ & $R^{2}$ \\
\hline \multirow{5}{*}{ C. regium } & Atatürk Dam Lake (Oymak, 2000) & 725 & $13.0-30.5^{*}$ & 3.0067 & 3.24 & 0.92 \\
& Sir Dam Lake (Kara and Solak, 2004) & 461 & $15.5-26.0^{*}$ & 0.0092 & 3.06 & 0.83 \\
& Seyhan Dam Lake (Ergüden et al., 2010) & 164 & $14.3-24.5$ & 0.0327 & 2.64 & 0.92 \\
& Almus Dam Lake (Suiçmez et al., 2011) & 359 & $13.7-28.1$ & 0.0039 & 3.28 & 0.98 \\
& Bibi-Sayyedan River of Semirom (Kiani et al., 2016) & 471 & $5.5-21.5$ & 0.0070 & 3.07 & 0.98 \\
& Zarrineh River (Radkhah and Eagder1, 2015) & 40 & $6.6-17.1$ & 0.0132 & 2.85 & 0.98 \\
B. lacerta & Sirvan River (Hasankhani et al., 2014) & 35 & $5.9-11.9$ & 0.006 & 3.28 & 0.97 \\
& Keban Dam Lake (Dartay and Gül, 2014) & 27 & $30.4-47.4$ & 0.0124 & 2.93 & 0.98 \\
& Bibi-Sayyedan River (Keivany et al., 2016) & 446 & $2.60-23.2$ & 0.0075 & 3.08 & 0.98 \\
\hline
\end{tabular}

n, sample size; Lmin, minimum length $(\mathrm{cm})$; Lmax, maximum length $(\mathrm{cm})$; *Fork length 
Table 4 Length-length relationships for two species, Karasu River

\begin{tabular}{c|cccc}
\hline Species & Equation & $a$ & $b$ & $R^{2}$ \\
\hline \multirow{3}{*}{ Chondrostoma regium } & TL= a + bFL & 0.869 & 1.017 & 0.98 \\
& FL= a + bSL & -0.126 & 1.092 & 0.99 \\
\multirow{3}{*}{ Barbus lacerta } & SL= a + bTL & -0.348 & 0.884 & 0.99 \\
& TL= a + bFL & 0.352 & 1.034 & 0.99 \\
\hline
\end{tabular}

The condition factors of the studied fish species were found to be between $1.102 \pm 0.013$ for $C$. regium; $1.176 \pm 0.019$ for $B$. lacerta. $C F$ values of $C$. regium and $B$. lacerta were $>1$ showing their perfect condition. The condition factor may vary among the fish stocks of same species in different location. High condition factor values demonstrate suitable environmental conditions, and low values indicate minor proper environmental conditions (Blackwell et al., 2000). Studies are available on the condition factor of $C$. regium and similar to our work (Oymak, (2000); Kara and Solak, (2004); Ergüden et al., (2010); Suiçmez et al., (2011)) and B. lacerta (Radkhah and Eagderi, 2015))

The results of this study (LWRs, LLRs and CF) could give useful insight for management plan and conservation of two species in Karasu River.

\section{References}

Ak O, Kutlu S, Aydın I. 2009. Length-weight relationship for 16 fish species from the Eastern Black Sea, Turkey. Turk J Fish Aquat Sci 9: 125-126.

Basusta A, Basusta N, Sangün L. 2017. Length-Weight Relationship of Brown Comber, Serranus hepatus, Linnaeus, 1758 from Iskenderun Bay, Northeastern Mediterranean, Turkey. Natural and Engineering Sciences, 2(1), 1-5. DOI: 10.28978/nesciences.292333).

Basusta A, Basusta N, Ozer EI, Aslan E, Girgin H. 2013. Some Population Parameters of The Lessepsian Suez Puffer (Lagocephalus suezensis) From İskenderun Bay, Northeastern Mediterranean, Turkey. Pakistan Journal of Zoology, 45(6): 1779-1782.

Blackwell BG, Brown ML, Willis DW. 2000. Relative Weight (Wr) Status and Current Use in Fisheries Assessment and Management. Reviews in Fisheries Science 8: 1-44.

Binohlan C, Pauly D. 1998. The length-weight table. In: R. Froese \& D. Pauly (Eds.), Fishbase 1998: Concepts, design and data sources (pp.121-123). Manila: ICLARM.

Ergüden SA, Göksu MZL, Avşar D. 2010. Growth properties of Chondrostoma regium (Heckel, 1843) living in Seyhan dam lake (Adana), Journal of Fisheries Sciences.com, 4: 391399.

Dartay M, Gül MR. 2014. Length-weight relationships for five fish species caught in Keban Dam Lake, Turkey. Journal of Applied Ichthyology, 30: 233-234

Froese R. 2006. Cube law, condition factor and weight-length relationships: History, meta-analysis and recommendations. Journal of Applied Ichthyology, 22: 241-253.

Hasankhani M, Keivany Y, Daliri M, Pouladi M, Soofiani NM.
2014. Length-weight and length-length relationships of four species (Barbus lacerta, Pseudorasbora parva, Squalius lepidus and Oxynoemacheilus angorae) from the Sirwan River, western Iran. J. Appl. Ichthyol. 30, 206-207.

Radkhah A, Eagderi S. 2015. Length-weight and length-length relationships and condition factor of six cyprinid fish species of Zarrineh River (Urmia Lake basin, Iran). Iran J. Ichthyol. 1: 61-64.

Kara C, Solak K. 2004. Some biological properties of Chondrostoma regium (Heckel, 1843) inhabiting Sir Dam Lake (Kahramanmaraş), Kahramanmaraş Sütçü İmam University Journal of Science and Engineering, 7: 13-19.

Keivany Y, Dopeikar H, Ghorbani M, Kiani F, Paykan-Heyrati F. 2016. Length-weight and length-length relationships of three cyprinid fishes from the Bibi-Sayyedan River, western Iran. Journal of Applied Ichthyology, 32: 507-508

Kiani F, Keivany Y, Paykan-Heyrati F, Farhadian O. 2016. Age and growth of king nase, Chondrostoma regium (Cyprinidae), from Bibi-Sayyedan River of Semirom, Isfahan, Iran. Iranian Journal of Fisheries Sciences, 15(3): 1214- 1223

Le Cren ED. 1951. The length-weight relationships and seasonal cycle in gonad weight and condition in the perch (Perca fluviatilis ). Journal of Animal Ecology, 20: 201-219.

Ozcan EI, Serdar O. 2018. Length-weight and length-length relationships of red-spotted trout (Salmo trutta macrostigma (Dumeril, 1858)) in Karasu River (East Anatolia, Turkey), Ecologicial Life Sciences, http://dx.doi.org/10.12739/ NWSA.2018.13.1.5A0091.

Oymak SA. 2000. The Growth Characteristics of Chondrostoma regium (Heckel, 1843) in Atatürk Dam Lake (Turkey), Turkish J. Zool, 24: 41-50.

Pauly D. 1993. Linear regressions in fisheries research. Journal of the Fisheries Research Board of Canada, 30: 409-434.

Sangun L, Akamca E, Akar M. 2007. Weight-Length Relationships for 39 Fish Species from the North-Eastern Mediterranean Coast of Turkey. Turkish Journal of Fisheries and Aquatic Sciences, 7, 37-40. http://doi.org/

Suiçmez M, Yılmaz Ş, Şeherli T. 2011. Age and Growth Features of Chondrostoma regium (Heckel, 1843) from Almus Dam Lake, Turkey. SDU Journal of Science (EJournal), 6 (2): 82-90

Tesch FW. 1971. Age and growth. In: W.E. Ricker (Ed.), Methods for Assessment of Fish production in Fresh Waters. Oxford: Blackwell Scientific Publications.

Turker-Cakır D, Torcu-Koç H, Basusta A, Basusta N. 2008. Length-weight relationships of 24 fish species from Edremit Bay Aegean Sea. Naturel Applied Science. 3: 47-51. 